\title{
The Development Model of Woman Empowerment in Order to Increase Family's Food Tenacity
}

\author{
Eny Yuniriyanti ${ }^{1}$, Ririn Sudarwati ${ }^{2}$ \\ 1. Technology Faculty of Merdeka University Malang \\ 2. Economic Faculty of Merdeka University Malang \\ Email: Enyuni@gmail.com, Ririn_Sudarwati@yahoo.co.id
}

Received: August 24, 2016; Accepted: December 11, 2016; Published: March 2, 2017

Permalink/DOI: http://dx.doi.org/10.17977/um002v9i12017p040

\begin{abstract}
This research is conducted with the intention to find the design of women empowerment role model in the attempt of increasing family food security. This finding will be utilized as the basic development plan which related to the efforts of achieving the family food security on the basis of local wisdom. By applying the questionnaire survey method, questionnaire will be analyzed by the descriptive analysis, correlation analysis, and crosstab analysis. The result of research shows that the attempt of family food security in the highest priority is to divert or to switch the staple food from rice to the other type of cheaper staple food (for instance corn). This a very common condition as the most easily found and bought staple food, to substitute rice, is corn. Meanwhile the most consumed side dishes in our society are the soybean cake (tempe) and tofu (tahu), while chicken and other meats are the less consumable side dishes in our society. For vegetable, Spinach is the most consumed vegetable as this species is easy to be planted around the house/yard. Based on the pre-set criteria, the condition of family food security in the research locations are 16\% in secured level and the rest, $84 \%$, is in insecured level.
\end{abstract}

Keywords: Dasa Wisma PKK, The Family Food Security, local wisdom. JEL Classification: $\mathrm{O} 12, \mathrm{P} 46$

\section{INTRODUCTION}

The national development is the entire Indonesian citizens' effort in order to achieve National goal and National purpose, as instructed in the opening of Indonesian law base 1945 (UUD 1945). In general and in particular the agriculture sector development in reality is all effort which is done for increasing farmer prosperity living standard. In RPJPN 2005 - 2025, one of the main objectives of economic development upcoming 20 years is food autonomy can be maintained on secure level and on sufficient nutrient quality and instrument of food guarantee on hand for family level which is supported by variety food sources appropriate with local wisdom. Local wisdom is a kind of surrounding wisdom that exist in community life at certain place or area that constitute system value or local community life behavior interact with community living place wisely (Chavis \& Wandersman, 1990). Therefore, the local wisdom is not the same either on the place and a different time and different 
tribe, so their experience in providing their daily needs shows various knowledge system both that are associated with community and social.

National food security is a strategic issue for Indonesian (Timmer, 2004). Effort to stabilize food cannot be separated from the handling of food insecurity due to food insecurity can be a cause of instability of food security (Quisumbing et al., 1995). Food insecurity can be caused by chronic problems such as capabilities, as well as temporary problems like afflicted by disaster or natural disaster (Szabo, 2016). In develop country, poverty and food insecurity is the main problem to be faced in food security development, whereas it is a prerequisite to fulfill the food rights of every human being. Strengthening of national food security is the goal and the objective to be realized through the hard work of whole nation components. In Indonesia, in an effort to achieve food security and for uniting effort between government and all community components to develop national food security, the government had set public policy of food security (KUKP) 2010-2014 which affirm, that the aim of food security development is to ensure the supply and enough food consumption, secure, excellent, and nutritionally balanced at the family level, regional, national all the time and equally through the resource utilization and local culture innovative technology and market opportunity, also strengthening the village economy and elevate the community from poverty. The book was published basically is public policy which lead to community empowerment to actualize the food security at family level as toehold of regional and national food security (Riley \& Moock, 1995).

Women as part of nation component take apart on an effort to realize food security especially family food security. The matter of women research in development is the global issue becomes an attention all nation including Indonesia. This is always a hot issue to be discussed by various parties both government and the woman's problem observer. That condition brings the positive effect because the effort of woman's part enhancement is not seen as a random without science foundation anymore, yet the awareness of woman's part exactly also has science knowledge that supports it. Different concepts and approaches for woman's part program in the establishment are introduced and tested to be implemented in the third world of woman's development projects (Nuniek \& Kartini, 1998).

On agriculture sector, the woman does not only produce and processes the crops, but they are also responsible on marketing of the crops and other commodities. And so, the female worker is the important part of the agriculture worker in various developed countries and developing countries. Women's contribution is also shown by their high responsibility on domestic work. Therefore, the intensity of female worker is not only high on agriculture production activity but also in family activity. Mr. Sukiyono and Mr. Sriyoto's research result (1997), for example, found that women (wife) are still capable to contribute $60 \%$ from the total workers who are needed to work on palm oil farm in Sri Kuncoro Village, North Bengkulu district, apart from their contributions on domestic activities and side work.

Further on, women also play the important role on food production phase, including the process and the food preparation. In many poor countries where their economies are depended on agriculture, less than $60 \%$ from the total poor 
people are women, where they are depended on agriculture for living (Markus, 1994; Danida, 2008; Wang et al., 2011). Village women are responsible for 60$80 \%$ food production in developing countries, although female farmer are often neglected in policy and agriculture development strategy (Purwantoro \& Mustofa, 2009).

However, many factors become an obstacle for the increase of women's role on the establishment in the community generally restricted by old tradition and culture (Ali et al., 2011). Understand and patriarchal practice that is motivated by culture and religion sanctions and also illiteracy, for instance, limit the women's freedom to select various choices in social interaction. As a result, women's contribution on agriculture and other sectors is still hard to be counted, especially on the effort to see their economic performance. Women often experience discrimination and limited on reproduction part and neglect their access to the resource which actually could increase their social economic contribution in the community (Prakash, 2003).

Women's role on the agriculture sector, especially their contribution on income and resources, have often investigated and analyzed, such as the example which was mentioned previously. On the other hand, women also have an active and important role on food security. Some research showed these, take a look, for example the research of Quisumbung et al. (1995) where they found that women played an important role on family's food security. However, the data analysis on the individual woman, husband, and their children seems need to be analyzed in more detail, especially related on the influence of women's status to food security. This is important considering so far it is very difficult to find the research which relates between women and family food security in Indonesia. Therefore, this research tries to find, meet and examine the correlation between women in family and the attribute which stick on their family to their family's food security.

Malang district is the second biggest district in East Java, the territory is $3.534,86 \mathrm{~km}^{2}$ wide and the total population 2.446 .218 people (the year 2010). The soil condition in north Malang district relatively fertile, while in the south part relatively less. Generally, people in Malang work as a farmer, especially who live in the village area, while Pagak subdistrict is one of the subdistricts in Malang district which is located around $12 \mathrm{~km}$ from the capital city of Malang (Kepanjen) toward the south. Majority people work as a farmer and labor. Most of population on subdistrict Pagak gets their main income from agriculture. Around 19.845 family are depended themselves on agriculture (farmer, farmer-labor, animal farm, fish farm). The expected aims of the research are as follow: 1) To find out the achievement of food security on farmer's family. 2) To find out the factors which influence the achievement of food security on farmer's family. 3) To synergy with The Food Security Agency and The Implementing Counseling (BKP3) in an effort to find out the model design of women's empowerment in effort of increasing food security accomplishment on farmer's family in Malang district. 4) To determine the model design of women's empowerment in effort of increasing food security accomplishment. 


\section{METHOD}

\section{Operational Definition of Variables}

1. Food availability is carbohydrate food product which is consumed by farmer's family include rice, corn and all kind of tuber.

2. The food access is the capability of farmer's family to obtain enough food, either comes from own production, stock, loan or food aid.

3. Utilizing food is the ability of farmer's family to utilize food efficiently appropriate with nutrient norm and health.

4. Food security is the food need for every single family is fulfilled.

5. Family is one or a group of people who live under the same roof, produce the food from the same kitchen and make economy decision together judging by the number of family, family's economy activity.

Table 1. Criteria of Family's Food Security Conditions

\begin{tabular}{cll}
\hline \multicolumn{1}{c}{ Status } & \multicolumn{1}{c}{ Criteria } & \multicolumn{1}{c}{ Explanation } \\
\hline \multirow{2}{*}{ "Secure" } & Really can stand & Never experience lacking food \\
\cline { 2 - 3 } & Can stand & $1-2$ times a year experience lacking food \\
\cline { 2 - 3 } Normal & Cannot stand & $1-2$ times a month experience lacking food \\
\cline { 2 - 3 } "Insecure" & Really cannot stand & Several days in a week experience lacking food \\
\hline
\end{tabular}

Source: Primary data is processed

\section{Type of Data}

Type of data in this research is primary data, in the form: 1) Portrait and farmer's family characteristic (family condition, age, total of children); 2) Variety or diversity of food which is consumed; 3) The source where the food product is being obtained; 4) People perception of food security; 4)The effort of community to overcome the food security problem

\section{Population and Sample}

Population and sample in this research is the farmer's family in the village of subdistrict Pagak, Malang district. The sample is determined by using purposive sampling or called criterion-based selection. In subdistrict Pagak, Sumbermanjing village is a village with the widest agriculture land, which is $251 / 448 \times 100 \%=56 \%$, compared to 7 (seven) other villages, so it has the highest total of farmer's family. The sample which is taken is a farmer's family which has the leader of the family (husband) and the housewife.

\section{Research Location}

Research location is conducted in the subdistrict Pagak in Malang District. Subdistrict Pagak is one of region 33 subdistricts in the area of Malang district, Astronomically it is located between 112,2966 - 122,3312 longitude, and 8,1827 $-8,11146$ latitude. Geographical location of the whole village is located on a plain with village plain topography classified. While the village relatively located in the forest, 4 villages are located outside of the forest, 4 villages are located on the edge of the forest. The width of subdistrict Pagak region in total $90,08 \mathrm{~km}^{2}$ or around 3,03\% from the total width of Malang district, is the calcareous hilly area. Geographically located that adjoin with sub-district Kepanjen to the north, subdistrict Donomulyo to the south, subdistrict Bantur the east and sub-district 
Kalipare to the west. Subdistrict Pagak consists of 8 villages and 21 hamlets, 77 RW, 330 RT with a total population around 50 thousand people. Pagak village has $19 \mathrm{RW}$ and $69 \mathrm{RT}$, Sumbermanjing Kulon village has $15 \mathrm{RW}$ and $58 \mathrm{RT}$, Tlogorejo village has $9 \mathrm{RW}$ and $37 \mathrm{RT}$, Sumberkerto village has $6 \mathrm{RW}$ and 29 RT, Pandanrejo village has $6 \mathrm{RW}$ and 24 RT, Sempol village has $9 \mathrm{RW}$ and 37 RT, and Gampingan village has $3 \mathrm{RW}$ and $22 \mathrm{RT}$.

\section{Data Collection Technique}

Data collection technique is done by using qualitative and quantitative approaches.

1. A qualitative approach is done by in-depth interview to the research respondents to obtain the same perception and digging out some information which are needed.

2. The quantitative approach is done by using questionnaire structured to the research respondents.

\section{Data Analysis Technique}

1. Descriptive Analysis

The data which obtained is tabulated, processed, reviewed, and discussed descriptively so that it can serve as information for decision making.

2. Crosstab Analysis

Crosstab analysis is an analysis method that has table form, which showing crossed tabulation or contingency table that is used to identify and knowing whether there is a correlation or a relation between one variable and others. This analysis is needed in term of development planning.

\section{RESULT AND DISCUSSION}

\section{Sumbermanjing Kulon Village Profile}

Sumbermanjing Kulon village is a village with hilly topography. The distance of the village to capital subdistrict is $12 \mathrm{~km}$ with long mileage 0,5 hour by motorcycle, while the mileage to the capital district of Malang around $40 \mathrm{~km}$ away with long mileage 1,5 hours by motorcycle.

\section{The Potential of Natural Resources}

Land which is available for farming and horticulture crops in Sumbermanjing Kulon village, especially comprised of wetland, both irrigated or not also dry land in form of fields and land which is temporarily not planted, with the de detail as follows:

The width of wetland (sawah) : 325 ha

The width of farming crops (Kebun) : 228 ha

Field (tegal/ladang) : 228 ha

Other Filed, yard (pekarangan) : 209,5 ha

\section{Extensive Crops and Production by Commodities}

The biggest crop productivity through the Sumbermanjing Kulon village are peanuts and then in consecutive is cassava, upland rice, maize, and rice paddy or wetland rice. 


\section{Results of Plant and Crop Area Fruits}

A production fruits crop in Sumbermanjing Kulon village is relatively big and potential to be increased of its productivity because the existing land has not been planted optimally yet. The biggest productivity crop is snake fruit.

\section{Spacious and Plantation Crops According to the Type of Commodity}

Sugar cane plantation has the biggest filed compared to other commodities also has far higher productivity so it becomes the most contributions production compared to other crops.

\section{Human Resources Potential Population composition}

From the population, composition shows that the number of female population is bigger than male. Female population as many as $53 \%(4552 / 8559 \mathrm{x}$ $100 \%)$ while male population is $47 \%(4107 / 8559 \times 100 \%)$. The total working female population is (498), the $60 \%(300 / 498 \times 100 \%)$ are working as a farmer, $31.5 \%(157 / 498 \times 100 \%)$ are working as a farmer-labor, $2 \%(10 / 498 \times 100 \%)$ are retired, $0.2 \%(1 / 498 \times 100 \%)$ is artists and $6 \%(30 / 498 \times 100 \%)$ private employees. Most of Sumbermanjing Kulon village's population are Moslem $(8212 / 8559 \times 100 \%=96 \%)$ and $100 \%$ are Indonesian citizen, $99.9 \%(8553 / 8559$ $\mathrm{x} 100 \%)$ are Javanese.

\section{The Relationship of Age with Food Security}

The relationship of age with food security is used for crosstab analysis with Spearman Correlation Methode which is shown on the following table:

Table 2. The relationship of age with food security

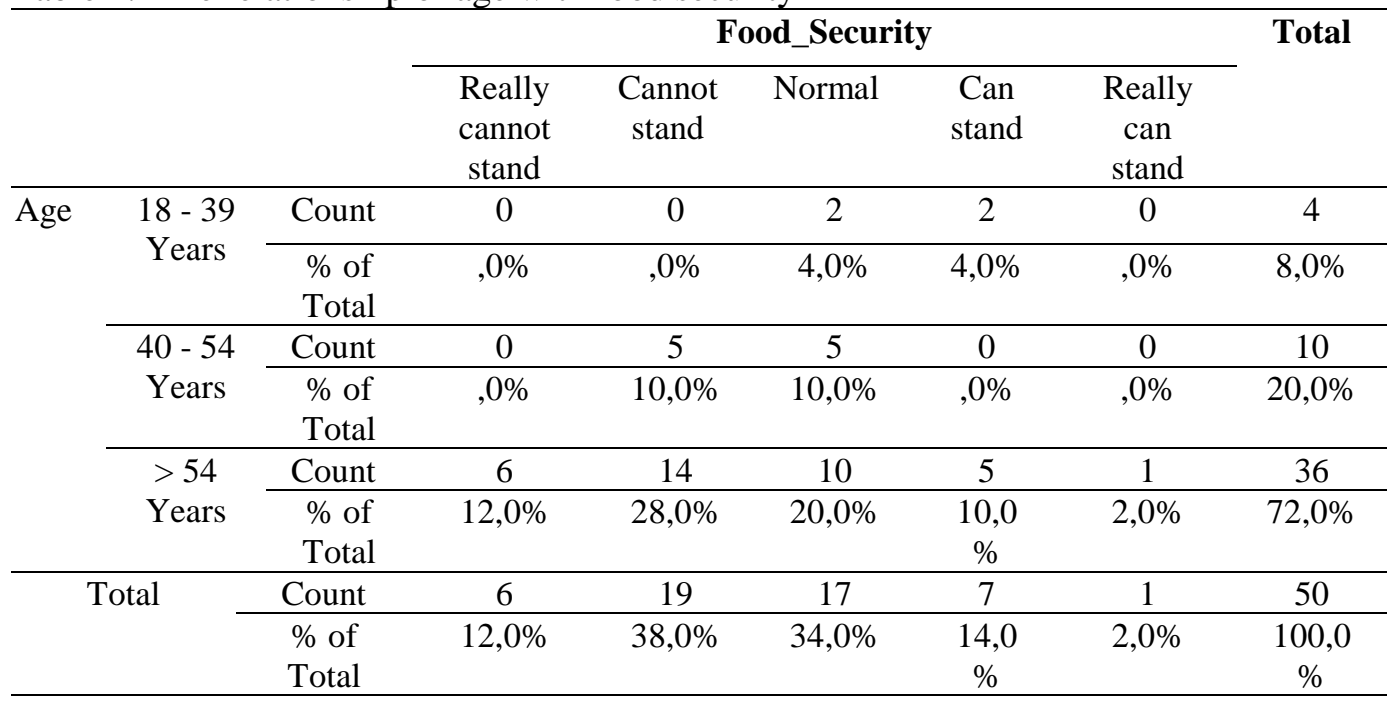

Source: Primary data is processed

Based on table 2 above it shows that the total respondents from age 18 to 39 years old have average food security criteria as many as 2 people (3\%). While the number of respondents with age range from 40 to 54 years old has average food security criteria as many as 5 people $(10 \%)$. Total respondents who are older than 54 years old really have poor food security criteria which are 14 people 
(28\%), so it can be concluded that the most respondent who has poor food security are those who are older than 54 years old.

It also can be concluded that the age with food security, has value $r$ correlation count, Spearman count $(-0,209)$ is smaller than $r$ table count $(0,279)$ and significance value $(0,149)$ is bigger than real level $(5 \%)$, so it can be decided to receive Ho. This identify that there is not enough fact to state that there is a significant relationship between age and food security. The negative sign on the correlation value shows that the relationship between age and food security is inversely proportional. It means the higher the age; it will lower food security level. This value stays on weak relationship criteria because it is on the $0,1-0,3$ scale.

\section{Relationship between the Profession and Food Security}

The relationship between the Profession and Food Security uses Spearman Correlation Methode which is shown in table 3 as follow:

Table 3. The relationship between the Profession and Food Security

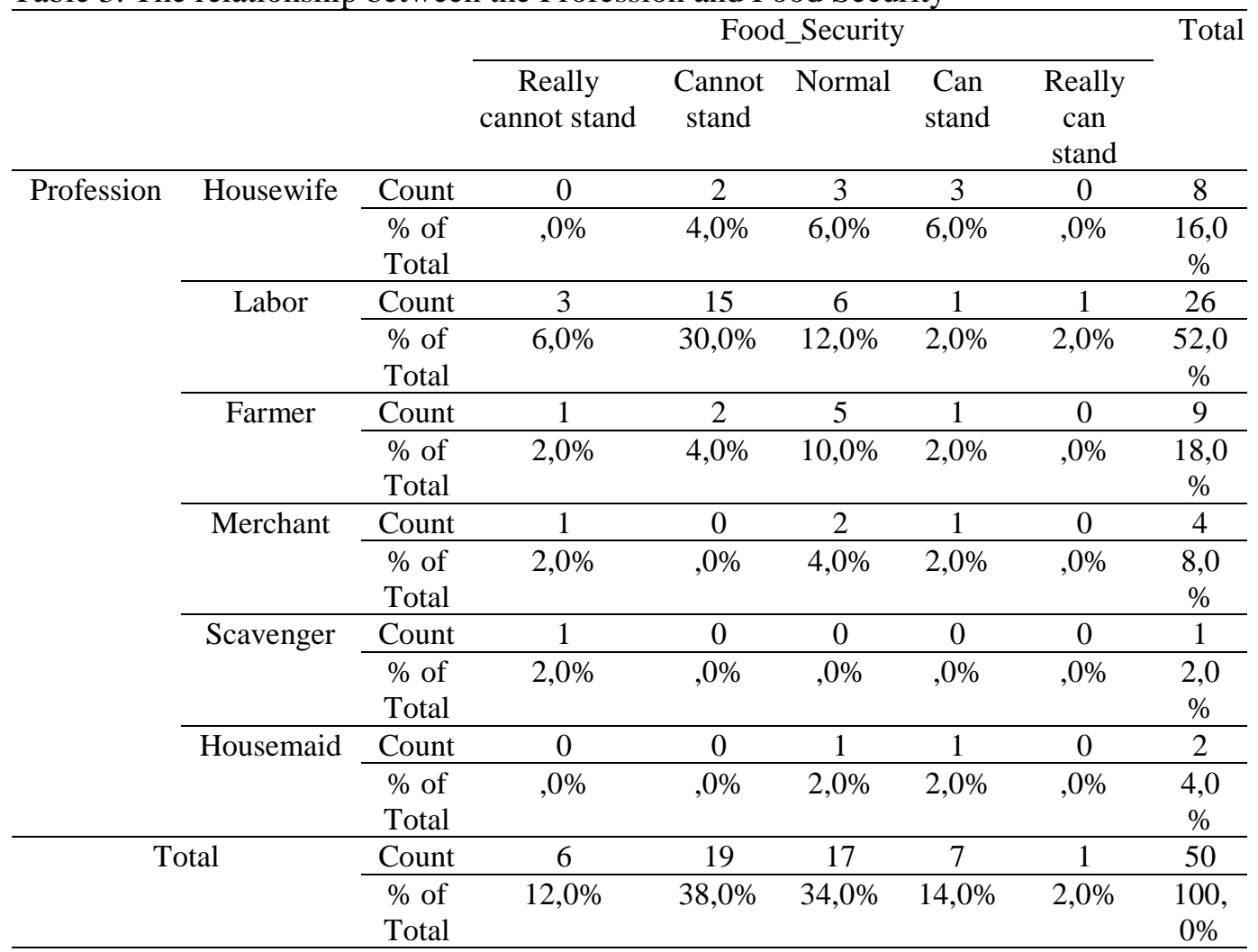

Source: Primary data is processed

Based on Table 3 above it shows that the number of housewife respondents have an average food security as much as $3 \%$. The numbers of housemaid respondents have an average food security as many as 1 person (2\%). It also can be concluded that the labor respondents as many as 15 people (30\%) have a poor food security criteria and it can be interpreted that some of the respondents based on the profession have lower food security.

It can be concluded that the profession with food security, has $r$ correlation count, Spearman count $(-0,019)$ is smaller than $r$ table count $(0,279)$ and the 
significant value $(0,898)$ is bigger than real level $(5 \%)$, so it can be decided to receive $\mathrm{H} 0$. This indicates that there are not enough facts to state that there is a significant relationship between the profession and food security.

The Relationship between Education and Food Security

Table 4. The Relationship between Education and Food Security

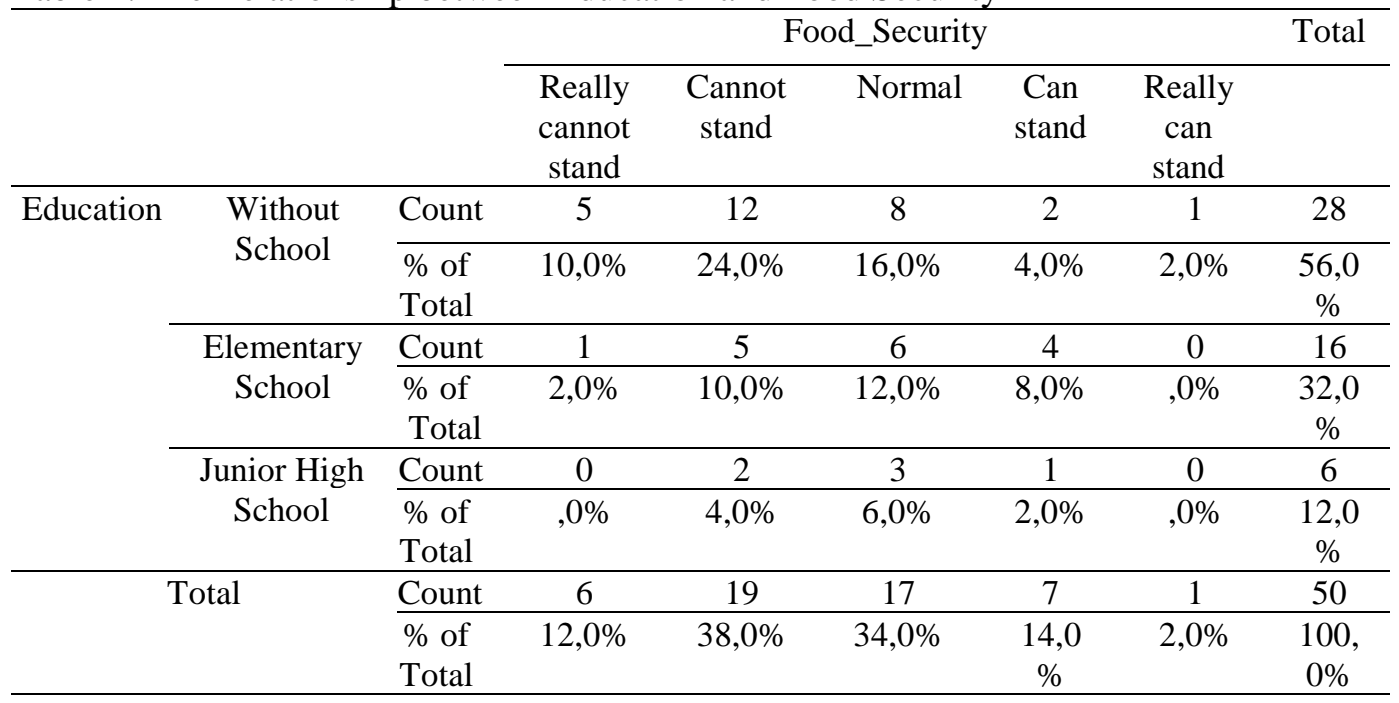

Source: Primary data is processed

Based on table 4 above, it shows that the total respondents without education have poor food security criteria as many as 12 people (24\%), cannot stand criteria as many as 5 people (10\%) and the really can stand criteria is only 1 person $(2 \%)$. Total respondents with Elementary School education with so-so criteria as many as 6 people (12\%) is bigger than the other criteria. While the total respondents with Junior High School education have average food security criteria as many as 3 people $(6 \%)$ is bigger than other criteria. Based on that table, it can be concluded that the most respondents who have cannot stand criteria as many as 12 people can be interpreted that some of the respondents have food security based on education.

\section{The Relationship Number of Children and Number of Family Expenses with the Effort of Food Security}

Table 5 The Test Result Statistic Analysis Rank Spearman Number of Children and Number of Family Expenses with Food Security.

\begin{tabular}{ccc}
\hline \multicolumn{2}{c}{ Variable } & Food Security \\
\hline Number of_Children & Correlation Coefficient &, 411 \\
& Sig. (2-tailed) &, 003 \\
& $\mathrm{~N}$ & 50 \\
\hline Number of_Family_Expenses & Correlation Coefficient &, 415 \\
& Sig. (2-tailed) &, 003 \\
& $\mathrm{~N}$ & 50 \\
\hline
\end{tabular}

Source: Primary data is processed

Based on the table 5 above can be obtained that significant number of children with food security has smaller real level $5 \%$, which is the error rate is 
determined prior to the study, which means there is enough facts to state that there is a significant relationship between number od children and the effort of food security as much as 0,411 . The positive sign of correlation value.shows there is a relationship, and it is directly proportional, between number of children and food security. It means the higher number of children and so will increase the food security level.This value stays on evererage relation criteria becase it is on $0,30-$ 0,60 scale. On that table also can be seen that significant value number of family expenses with food security has smaller real level $5 \%$, which is the error rate is determined prior the study, which means there is enough facts to state that there is a significant relationship between number of family expenses and food security as big as 0,415 . The positive sign on correlation value shows the relationship, and it is directly proportional, between a number of family expenses and food security. It means the higher number of family expenses and so will increase the effort of food security. This value stays on average relation criteria because it is on $0,30-$ 0,60 scale.

Based on the criteria which has already set, family's food security condition in Sumbermanjing Kulon village sub-district Pagak shown on the table as follow:

Table 6 Family's Food Security Condition

\begin{tabular}{|c|c|c|c|}
\hline Status & Criteria & Amount & Percentage \\
\hline \multirow{3}{*}{ "Secure" } & Really can stand & 1 & $2 \%$ \\
\hline & Can stand & 7 & $14 \%$ \\
\hline & & 8 & $16 \%$ \\
\hline \multirow{5}{*}{ "Insecure" } & Normal & 17 & $34 \%$ \\
\hline & Cannot stand & 19 & $38 \%$ \\
\hline & Really cannot stand & 6 & $12 \%$ \\
\hline & & 42 & $84 \%$ \\
\hline & & 50 & $100 \%$ \\
\hline
\end{tabular}

Source: Primary data is processed

\section{Research Implementation}

Development planning is an early stage in the development process. The important of planning is used to complete the objectives to be achieved in the development of the potential of available resources as well as other alternatives that may be required. Regional development planning is defined as a development planning process that is intended to make changes toward a better development for the community, government and the environment in certain regions, by utilizing or to leverage existing resource, and must have an orientation that is comprehensive, complete, but sticks to the principle of priority.

Based on the pre-set criteria, family food security condition in Sumbermanjing Kulon village in subdistrict Pagak secure status only is $16 \%$ and insecure status is $84 \%$. Sumbermanjing Kulon has abundant and diverse natural resources. The largest food crops land owned by Sumbermanjing Kulon village is maize, but the largest food crop productivity is peanuts than in consecutive cassava, upland rice, maize and paddy rice/wetland rice. While the fruit production plant in Sumbermanjing Kulon village is large enough and its productivity is potential to be improved because the existing land hasn't used optimally yet. The biggest productivity is snake fruit plants. Sugar cane plantation 
has the largest land and also has far higher productivity compared to other commodities so it contribute the largest production compared to other plantation crops.

Food security initiative undertaken by farmer's family with the highest priority is the main staple (rice) followed by the cheaper is maize. It is quite natural for food crops instead of rice were easily found and bought corn than other crops. As for the side dishes were often consumed by people is tempeh and tofu, only a small fraction ever consumed much less meat chicken. Vegetables are most often consumed are spinach because it is easily grown around the house/yard. Food processing is often done simply by boiling or frying without any diversification so that the nutritional value is relatively fixed and the same in every processed. Women as housewives in addition to its role to help her husband find an additional living for his family is also responsible for the management of the family economy. They are always trying to manage it so that the various limitations can still eat a decent family and survive. It can be said women have an important role in improving the food security of the family (Kalansooriya \& Chandrakumara, 2014)

With these circumstances, Malang Regency Government through the Agency for Food Security and Agricultural Extension (BKP3) should give more attention and work to improve family food security conditions, not only for the village but for all Sumbermanjing Kulon villages in the district of Malang.

\section{Building Synergy with the Agency for Food Security and Agricultural Extension (BKP3)}

The general objective of Food Security Development and Implementation of Agricultural Extension is to create and develop a food security system that is powerful, dynamic and synergistic and to realize the revitalization of education and improve the welfare of farmers (Padhy \& Jena, 2015). This is achieved through the development of sub-systems of food availability, food consumption sub-systems, food distribution, food quality and safety with regard to the potential, diversity of food resources and culture and local culture.

The strategy of the Food Security and the Implementation Guidance is as follows:

\section{Food Security Strategy}

a. Developing food security coordination forum District and Sub-district level.

b. Increasing public participation in the overall food security system.

c. Develop diversification of food production and food consumption based on local resources.

d. Build preparedness officials and the community in anticipation of the issue of access, insecurity, and food security.

\section{Implementer Counselling Strategy}

a. Develop coordination forum district and sub-district level extension

b. Improving the quality and professionalism of EA

c. Improved systems work by actualizing 1 Village - 1 Instructor 
d. Realizing a career path as well as the system of rewards and sanctions for the instructor

e. Realignment of the functions instructor based farmers' needs.

f. Institutional restructuring of farmers

g. Optimization of resources in agriculture, fisheries and forestry based on a local specification

h. Development of methodologies and models of participatory counseling

i. Increased institutional farmers into independent strong social economy institution

j. Networking and technological development of agribusiness

\section{Food Security Programmes}

1. Development of Village's Food Independent (Demapan)

Demapan activities are: (1) one of the strategies to accelerate development in rural areas, particularly in strengthening food security; (2) activities across sectors in its implementation requires the involvement and synergy among institutions and stakeholders; and (3) the integration of developing a form of development programs of central, provincial, and district in the countryside. Component activities, through approach: community development, institutional strengthening, development of food security and rural infrastructure support for the proposition through cross-sectoral coordination in the container Food Security Council. The activities carried out in stages, provincial and district levels to conduct training in the villages' implementer. Planning at the village level is done participatory, involves:

2. Food Consumption Diversification Acceleration (P2KP)

$\mathrm{P} 2 \mathrm{KP}$ movement is an effort to realize increased diversification and is one key to the success of agricultural development in Indonesia. P2KP conducted in three main forms of activities, namely: (a) Optimizing the Utilization courtyard through the concept of Sustainable Food Houses Region; (B) Development of Local Food; and (c) Promotion and socialization of P2KP. P2KP activities have been carried out since 2010 to the present with a variety of targets and achievements are growing. Movement P2KP implemented through advocacy, socialization, and promotion. Advocacy is done by the Governor and Regent/ Mayor to issue local regulations regarding P2KP, and so far, there have been published approximately 100 regional regulations in the form Pergub/Perbup/ Perwalikota or leaflet.

Socialization is done through the efforts of counseling to the woman (mother) and early childhood on the pattern of food consumption Variety, Nutritious, Balanced and Safe (B2SA), dissemination of information to functionaries about the Presidential Decree No. 22 of 2009 and the minister of agriculture Decree No. 43 of 2009, semi-documentary films production about local food in six provinces, as well as advertisements in the mass media either single broadcasting in radio as well as viewing public service ads on television. Promotion is done by conducting food diversification exhibition together with functionaries, especially business people, creation competition B2SA together with PKK activator's team, as well as the promotion of local food production materials. 
3. Strengthening Institutions of Food Distribution Society (Strengthening LDPM)

LDPM Strengthening activities carried out in the framework of the protection and empowerment of farmers / Farmer's group (Kelompok Tani)/rice and corn farmers group's role (Gapoktan) towards the price fall at harvest time, and the problem of accessibility of food in times of shortage. StrengtheningLDPM activities carried out through several stages: Stage Growth, Development Phase, and Phase Independence.

\section{PDRP (Pelaksanaan Penanganan Daerah Rawan Pangan)}

For the handling of food, insecurity interventions are required in the form of action taken by the government together with the community in tackling the incidence of transient and chronic food insecurity, to address the people who experienced food insecurity in accordance with their needs accurately and quickly. Chronic food insecurity requires a medium- and long-term intervention, while food insecurity transient short-term interventions required an immediate emergency response. To optimize and synergize the roles of government, local governments and communities in the prevention and handling of food insecurity, prepared Guidelines for Handling Food prone regions, as a reference in Prone Areas of Food Handling activities.

\section{Implementation Region Sustainable Food House Program}

The Ministry of Agriculture initiated the optimization of the utilization of the yard through the concept of Sustainable Food House (RPL). RPL is home residents who undertake intensive yard to be used with a variety of local resources wisely which ensures continuity of supply of household food quality and variety. If the RPL developed in large scale, based hamlet (village), village, or other areas that permit, the application of the principles of Sustainable Food House (RPL) is called Region Sustainable Food House (KRPL). In addition, KRPL also includes the intensification of the use of a living fence, village roads, and other public facilities (schools, houses of worship, and others), green open land, and developing processing and marketing results.

The basic principle KRPL are: (i) utilization of the yard that are environmentally friendly and designed for durability and food self-sufficiency, (ii) diversification of food based on local resources, (iii) the conservation of genetic resources of food (crops, livestock, fish), and (iv) maintaining sustainability through the village to the nursery gardens (v) increase in income and social welfare.

One important justification of the development area of Sustainable Food Houses (KRPL) is that national food security should start from food security at the household level. Since the year 2010 to the year 2012 as many as 5700 villages spread over 363 districts/cities in 33 provinces with the target group is women's group has been conducting optimizing utilization of the yard, and in 2013 planned to have 5000 new village spread over 497 districts/cities in 33 the province will undertake optimizing utilization of the yard through the concept of Sustainable Food Houses Region (KRPL).

East Java has the potential of natural resources are quite large and have not been used optimally, especially agricultural development, while on the other hand every year going over the agricultural land to non-agricultural and food demand will continue to increase along with the increase of population. East Java has an 
area of $47157.72 \mathrm{~km} 2$ with a potential fairly spacious yard around 626.740 hectares and the number of families as much as 10,355,261 households. Of the number of households is still relatively small yard ground for the development of agriculture. To answer that East Java has made the concept of "Home Zone Development Sustainable Food Plus Plus" Hereinafter referred KRPL ++. This program is a movement of and for rural communities start village level up to the household level and cooperate with the mothers of the PKK began the provincial level up to the level dasawisma, as well as take advantage of women's cooperatives, and Posyandu.

The main purpose KRPL ++ Development models are

1. Increasing the availability and family food reserves

2. Increase the diversification of food

3. Improving the nutritional quality of family

4. Increased family income

5. Develop creative economy in every village

\section{THE MODEL OF WOMEN'S EMPOWERMENT \\ IN EFFORTS TO ACHIEVE FAMILY'S FOOD SECURITY}

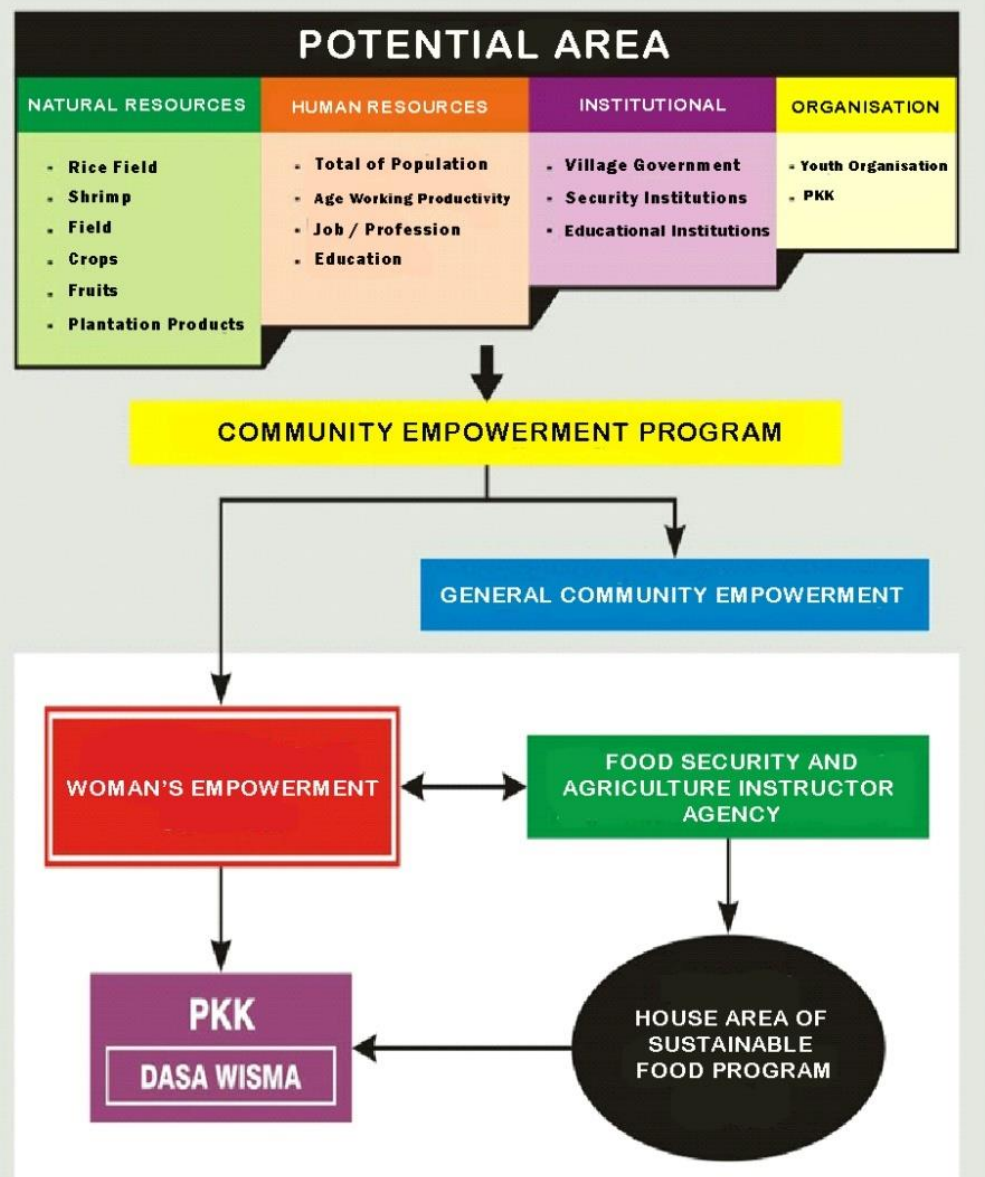

Figure 1. Model of Woman Empowerment in Effort to Achieve Family's Food Security 
The main target KRPL ++ Development Model is a whole village in East Java through:

1. Empowerment housewives who joined the PKK village and Dasa Wisma as a field manager.

So far the PKK has been so institutionalized both at the central, provincial, district, subdistrict and village levels. PKK with various activities in the implementation penetrating through the hamlet level, RT, and Dasa Wisma through the implementation of 10 PKK principal programs namely: 1 . Appreciation and practice of Pancasila; 2. Mutual cooperation; 3. Food; 4. Clothing; 5. Housing and households managing; 6. Skills and education; 7. Health; 8. Life of cooperatives development; 9. Preservation of living environment is alive; and 10. Health planning. Dasa Wisma is a group of mothers came from 10 to 20 neighboring home. Dasa Wisma group consists of 10 to 20 head of families (KK) in one RT. Once the group is formed, then one person was appointed to have a responsibility as chairman. The objectives of the Dasa Wisma groups are helping the smoothness of the main tasks and PKK village program. Dasa Wisma as one of the community activities coordinating institution has a very important role in the implementation of PKK's activities programs at the village level, which will also affect the movement activities PKK in the subdistrict and district levels.

2. Developing of village garden seedling and other supports Village garden seedling is an important medium to exist.

This garden seedling is also managed by trained women in PKK, so it can bring a variety of plants in.

3. Improving the women's cooperation role in every village.

Sustainable food home which is managed by women in PKK is hoped to be able to improve optimally. Its management will be better when it is collaborating with women's cooperation, so to be expected it can improve more income for the family both individually, Dasa Wisma and village.

4. Improving the integrated service post (posyandu).

Posyandu is a unit of integrated services in the areas of health and nutrition of the family. Periodically the pregnant mothers, children under five and breastfeeding mothers gather to receive health services. This is where the crops can be socialized and consumed.

KRPL ++ development targets in East Java in the year 2016 are whole villages which are 256 villages.

\section{CONCLUSION}

There is not enough evidence to state that there is a significant relationship between age and food security. The negative sign of correlation values showed the relationship of age with food security is inversely proportional. This means that the higher or increased of the age, it will reduce the level of food security. There is not enough evidence to state that there is a significant relationship between the profession and food security. The negative sign of correlation values showed an employment relationship with food security is inversely proportional. This means that the higher a person's work will more and more reduce the level of food security. This value is the criteria relationship is very weak because it shows from 0 to 0.1 on the scale. 
Most respondents with criteria cannot stand as many as 12 people may mean that some of the respondents have a low food security based on education. The higher the number of family expenses, it will increase the food security effort.Based on appointed criteria, family food security conditions in the village Sumbermanjing Kulon subdistrict of Pagak is only $16 \%$ secure and $84 \%$ secure insecure. The region of Sustainable Food House (KRPL) that is managed by the PKK incorporated in Dasa Wisma is formed as an effort to increase the security of families. The research needs to be continued by persisting synergies with the Food Security and Agricultural instructor (BKP3) Malang district in an effort to ensure the sustainability of the implementation Region Sustainable Food House (KRPL) program.

\section{REFERENCES}

Ali, T. S., Krantz, G., Gul, R., Asad, N., Johansson, E., \& Mogren, I. (2011). Gender Roles and Their Influence on Life Prospects for Women In Urban Karachi, Pakistan: A Qualitative Study. Global Health Action, 4(1), 1-9.

Chavis, D. M., \& Wandersman, A. (1990). Sense of community in the urban environment: A catalyst for participation and community development. American journal of community psychology, 18(1), 55-81

Danida. (2008). Gender Equality in Agriculture. Ministry of Foreign Affair of Denmark. Denmark.

FAO. (1996). World Food Summit, 13-17 November 1996. Rome, Italy: Food and Agriculture Organisation of the United Nations.

Kalansooriya, C. W., \& Chandrakumara, D. P.S. (2014). Women's Role in Household Food Security in Rural Sri Lanka. International Journal of Multidisciplinary Studies, 1(1), 41-54.

Markus, L. (1994). Konsep Dasar Jender. Makalah yang disajikan dalam Lokakarya Perlindungan Sosial Bagi Wanita Pekerja Rumahan. Jakarta.

Mustofa. (2012). Analisis Ketahanan Pangan Rumah Tangga Miskin Dan Modal Sosial di Provinsi DIY. Geomedia Jurnal Sains Geografi, 10(1), 1-21.

Nuniek, S., \& Kartini, J. (1998). Diskriminasi Terhadap Pekerja Perempuan Dalam Kebijakan Manajemen Perusahaan Garmen dan Tekstil di Kotamadya Semarang. Majalah Penelitian Lembaga Penelitian Universitas Diponegoro Tahun X 37, Maret.

Padhy, C., \& Jena, B. K. (2015). Effect of Agricultural Education on Farmers Efficiency: A Review. International Journal of Engineering Technology, Management and Applied Sciences, 3(2), 247-258.

Peraturan Presiden Republik Indonesia Nomor 83 Tahun 2006 Tentang Dewan Ketahanan Pangan

PPK-LIPI. (2004). Ketahanan Pangan, Kemiskinan dan Demografi Rumah Tangga. Seri Penelitian PPK-LIPI No. 56/2004. Jakarta: Puslit kependudukan _ LIPI.

Prakash, D. (2003). Rural Women, Food Security and Agricultural Cooperatives. Rural development and Management centre ;Teh Saryu'. J-129 Kalkaji, New Delhi 1100019. India. February 2003. New Delhi.

Purwantoro, S., \& Mustofa. (2009). Strategi Pencapaian Ketahanan Pangan Pada Rumah Tangga Miskin Di Provinsi DIY. Penelitian Stranas. UNY 
Quisumbing, A.R., Brown, L.R.,Feldstein, H.S.,Hahhah, L., \& Pena, C. (1995). Women: the Key to Food Security. Food Policy Statement. No. 21. International Food Policy Research Institute. August 1995, Washington.

Republik Indonesia. (2002). Peraturan Pemerintah Republik Indonesia Nomor 68 Tahun 2000 Tentang Ketahanan Pangan. Jakarta: Sekretaris Negara RI.

Riley, F., \& N. Moock, N. (1995). Inventory of Food Security Impact Indicators: Food Security Indicators and Framework, A Handbook for Monitoring and Evaluation of Food Aid Programs, Draft, IMPACT, Arlington, VA.

Sukiyono, K., \& Sriyoto. (1997). Transformasi Struktural Wanita Transmigran ke Luar Sektor Pertanian dan Kontribusinya terhadap Pendapatan Rumah Tangga (Kasus Transmigrasi Sekitar Kota Bengkulu). Jurnal Agroekonomika Bogor.

Szabo, S. (2016). Urbanisation and Food Insecurity Risks: Assessing the Role of Human Development. Oxford Development Studies, 44(1), 28-48.

Timmer, C. P. (2004). Food Security in Indonesia: Current Challenges and the Long-Run Outlook. Working Paper Number 48: Center for Global Development.

Undang-Undang Republik Indonesia Nomor 7 Tahun 1996 tentang Pangan.

Wang, C., Yang, Y., \& Zhang, Y. (2011). Economic Development, Rural Livelihoods, and Ecological Restoration: Evidence From China. Ambio, 40(1), 78-87 